\title{
EFFECT OF CULTURAL DIFFERENCES ON THE PRINCIPLE OF AUTHORITY INTRODUCED BY ROBERT CIALDINI
}

\begin{abstract}
Robert Cialdini, in his book Psychology of Persuasion, presented six fundamental principles that are present in human interactions. These are reciprocity, social proof, commitment and consistency, liking, scarcity, and authority. These principles are universal and can be observed, more or less, everywhere we go. They are present in all ways of life in every nation. Nevertheless, there are noticeable differences when discussing the principle of authority concerning cultural and political backgrounds between various countries. Beliefs, customs, traditions, values and principles form the foundations of any culture. Because these factors vary between different nations, so do their cultural elements. In this paper, a case study approach is used to examine those differences by examining British and Polish ways of recognizing and submitting to the Principle of Authority.
\end{abstract}

Keywords: principles, influence, authority, power, culture.

\section{INTRODUCTION}

In order to understand better Cialdini's (2009) Principle of Authority it is necessary to identify two concepts, namely the notion of authority and the notion of power. According to Cole (1998), the notion of authority refers to the "formal power to act, conferred on an individual to enable him to fulfil his responsibilities. It is usually fairly well-defined in order to limit the powers available to the individual". Max Weber distinguishes between patriarchal powers, which are non-authoritarian, consensual, arbitral and political powers, which are autonomous military and judicial authority (Roth, 1968). Political authority involves the power over life and death. Nonetheless, it binds a community together not only through this coercion but also through common historical experiences. Furthermore, Weber (1968) distinguishes three types of legitimate authority, namely traditional authority, charismatic authority, and legal or rational authority. Traditional authority, as the name suggests, is power that is rooted in tradition, beliefs and practices of a society. For example, in the nineteenth century, as stated by Dahl (1961), "[t] he elite seems to have possessed that most indispensable of all characteristics in a dominant group - the sense, shared not only by themselves but by the populace, that their claim to govern was legitimate". Traditional authority can be assumed on the basis of it being inherited or on religious grounds (where the society believes figures of authority are appointed by God). Rational or legal authority,

\footnotetext{
${ }^{1}$ Katarzyna Coombs-Hoar, M.A., the Institute of English Studies, University of Rzeszów, Al. mjr.
} W. Kopisto 2 B, 35-315 Rzeszów; e-mail: kat.sok@ op.pl. ORCID: 0000-0001-6177-0031. 
according to Weber (1968), derives from law and is founded on the belief in the lawfulness of a society's laws and rules. Therefore, while traditional authority is presented to an individual because of inheritance or divine appointing, rational or legal authority resides in the office or in a position that an individual holds. Charismatic authority is described as "resting on devotion to the exceptional sanctity, heroism or exemplary character of an individual person, and of the normative patterns or order revealed or ordained by him" (Weber, 1968). The author emphasises that this type of authority is less stable than traditional authority or rational-legal authority as it expires with the individual.

A more developed division of the notion of authority is that presented by Paterson (1966), who identifies five basic forms of authority. Sapiential Authority is based on a person's superior knowledge and experience; Moral Authority, which is possessed by a person trying to improve a situation; Personal Authority, based on a person's own qualities; Structural Authority, gained by reason of a person's position within an organisation; and Charismatic Authority, given by God.

\section{UNDERSTANDING POWER}

One way of studying and understanding power, according to Morriss (1987), is by cataloguing the authors' resources. The relationship between the notion of authority and the notion of power has been explored in depth by many authors. According to Bierstedt (2001), "[p]ower is not force and power is not authority, but it is intimately related to both and may be defined in terms of them". The author also adds that authority cannot exist without the support of power and the sanction of force (Bierstedt, 2001). Furthermore, on the topic of power Arendt (1970) states that power does not belong to an individual; it belongs to a group and exists only as long as the group remains together. In Lukes' Power a Radical View (2005) it is also stated that "the bias of the system is not sustained simply by a series of individually chosen acts, but also, most importantly, by the socially structured and culturally patterned behaviour of groups, and practices of institutions". While Russell (1938) defines power simply as the production of an intended effect, Parsons (2001) maintains that "the power is conceived as a circulating medium, analogous to money, within the political system. Therefore, specification of the properties of power can best be approached through an attempt to delineate very briefly the relevant properties of money as such a medium in the economy". According to Scott (2001), when discussing the notion of power it is vital to know "whether power involves only intended outcomes or whether unintended consequences of action may also count as features of the exercising of power" 2 . In the opinion of the author when considering the subject of the agent's intention, it is vital to recognise the conditions under which they are acting, specifically to what extent people are aware of the probable consequences of their actions and those of others.

\section{PRINCIPLE OF AUTHORITY}

Cialdini's Principle of Authority dictates that people are more likely to obey a request coming from a person with some power (2009). A great deal of research has been conducted to prove this theory, starting with psychology professor Stanley Milgram's 1974 test, where electric shocks were administered to subjects on order by someone in charge, an authority figure, a person in a white coat with a clipboard posing as an expert (Cialdini, 2009). Of

\footnotetext{
${ }^{2}$ Emphasis original.
} 
course, they were not real electric shocks, and the subjects receiving them were only trained actors, but the real study - the subjects of this experiment, namely the administrators of the shocks, were not aware of that fact. Implausible as it may seem the need to obey a figure of authority far outweighed any considerations of pity towards the 'victims' of the experiment. According to Milgram (2017) "[o]bedience is the psychological mechanism that links individual action to political purpose. It is the dispositional cement that binds men to system of authority". This experiment was only one of many tests performed to prove the theory of influence by researchers, but at some point in their lives all people are prone to blindly follow the instructions of an authoritative figure. Most visits to a local GP result in the patient obtaining prescriptions; however, rarely is the opinion of the doctor questioned; most of the time the note itself is impossible to decipher. Nevertheless, a journey is made to a chemist where another person in a white coat with a name badge hands over boxes with medications and writes on them how they should be administered: it is rare indeed for someone to challenge such authority.

As Cialdini (2009) states:

Conforming to the dictates of authority figures has always had genuine practical advantages for us. Early on, these people (for example, parents, teachers) knew more than we did, and we found that taking their advice proved beneficial - partly because of their greater wisdom and partly because they controlled our rewards and punishments. As adults, the same benefits persist for the same reasons, though the authority figures now appear as employers, judges, and government leaders. Because their positions speak of superior access to information and power, it makes great sense to comply with the wishes of properly constituted authorities.

In general people are perceived as experts mainly due to their knowledge and credibility. Both of these aspects are not something that can be deduced just by simply glancing at a person, but what can be noticed first of all is someone's appearance. Cialdini (2009) states that there are three symbols of authority: titles, clothes, and trappings. According to the author " $[\ldots]$ titles are the most difficult and the easiest symbols of authority to acquire. To earn one normally takes years of work and achievement. Yet it is possible for somebody who has put in none of this effort to adopt the mere label and receive a kind of automatic deference" (Cialdini, 2009). Clothing is, naturally, a more tangible symbol than a title. Whether it is a policeman's uniform, a doctor's white coat or a businessman's suit, when approached by a person wearing one of these, we would consider what they have to say, and when combined with trappings such as cars or jewellery their words carry great import. The principle of authority can be observed everywhere, but the depth and intensity of it will vary depending on the country's culture, traditions, and politics. The case study in this paper will compare the ways in which authority is perceived in the UK and in Poland.

\section{INFLUENCE OF RELIGION}

The culture of any given country consists of many factors such as beliefs, customs, behaviour, and the set of norms that exist within the populace of a sovereign nation. However, the biggest and the most influential component is religion. Religion dictates the rules to obey and values to follow. The role of a priest in Poland is not restricted simply to preaching during Sunday Mass, but to keep parishioners informed about everything that is going on in their church, starting with little things, such as whose turn it is to provide flowers 
for the altar and who is responsible for cleaning that week, and finishing with information regarding donations to the church. Congregants comply with the requests given by the priest (it is more noticeable in villages and small towns) because in Poland the priest holds a position of power, the power to refuse a wedding or a funeral, the power to deny christening or communion.

In the UK, priests do not hold such an influential position, they are respected in their community for the work they provide, running a church, organizing events, accommodating requests in regards to weddings or christenings, but they lack the same authority as priests in Poland. In the UK people frequently relocate, moreover many of the population work on Sundays. Therefore, it is difficult for any priest to keep track of their congregation. The UK is an exceptionally multicultural country with so many different faiths that the attempt to respect and to accommodate all of them has led to the dilution of the power and the authority of the Church of England (Worley, 2016). Having new doctrines set up to deal with continually changing ways of life (regarding gay marriages, gay vicars, tolerance toward other faiths and races, gender identity and fluidity) made people, especially the older generation, less inclined towards the church (Roberts, 2017). Religion in Poland is stronger because it is utterly inflexible and uniform, priests have more authority because they speak relatively in one voice, a voice that gives unified and straightforward commands, and therefore is easy to follow. The views of the Church as a religious institution are not only present during Sunday Mass, or during R.E. lessons at schools but also during major political debates, playing a vital role in the government's decision making. In some Polish school next to the national emblem hangs a cross, while in England the Archbishop of York, John Sentamu (n.d.), appraises diversity stating that " $[\mathrm{t}]$ he organizational culture of the Church of England [...] is still socially glued together by a culture that is monochrome that is white. [...] It lacks colour and spice".

However, the situation in Northern Ireland is different in that the dominant religion is Roman Catholic, 40.8\%, (Census, 2011). Northern Ireland is considered the most religious part of the UK where as much as $82 \%$ of its residents described themselves as Christian (Census, 2011). But even there a change is taking place. The Republic of Ireland has recently conducted referendums, one in May 2018 to allow abortions, and the second one in October 2018 regarding the removal of the law on blasphemy from the constitution (McSorley, 2018). The results of a YouGov poll carried out by Amnesty International UK in October 2018 show that 75 per cent of people in Northern Ireland want to follow in the Republic of Ireland's footsteps and change the abortion law (Amnesty International UK, 2018). Furthermore, in the absence of the Northern Ireland Assembly, an institution responsible for the subject of health, 66 per cent thought that Westminster should reform the law and make it compatible with the rest of the UK (Kelly, 2019).

\section{INFLUENCE OF SIGNIFICANT HISTORICAL EVENTS}

It has to be noted that it was Henry VIII, in 1534, who set the precedent for shaking off the authority by breaking away from the papacy in Rome to remarry (Pollard, 2007). This single act showed the masses that the symbol of authority could be easily replaced to suit one's needs. Moreover, even the authority of the king can be curtailed as shown by another example from the past, namely the Magna Carta (Breay, 2014). When Magna Carta was sealed, England had endured 16 years of John's kingship - a rule based mainly on extortion, legal deception, blackmail, and violence (Jones, 2015). However, it was not within the remit 
of the king's subjects to question the king's ways or condemn his actions; royal subjects were expected to obey the authority that the position of being the king brings. Magna Carta was created to curb the king's misuse of the loopholes in feudal customs, limiting payments funding wars, confirming people's rights under the common law of the land. For the first time in British history the king was a subject of the same law of the land as the commoners (Ibeji, 2011). Magna Carta laid down the principle that "No free man shall be arrested, or imprisoned, or deprived of his property, or outlawed, or exiled or in any way destroyed, nor shall we go against him or send against him, unless by legal judgement of his peers, or by the law of the land" ( BBC UK The British Museum). Moreover, the king was no longer above the law.

History shows that for the country to be strong there needs to be one leader above all; after the signing of the Magna Carta and the death of King John the country spun into a civil war, "For a society to be strong and stable there was a need for a powerful rule, with ultimate authority resting with one man. For a country to go to war, it needed a single, supreme military leader. Arguments between great barons could only be settled if both agreed to submit to the judgement of one superior overlord" (Jones, 2015).

These two examples from British history, namely Henry's VIII disowning of Papal supremacy and Magna Carta's curbing of the king's powers, provide us with insights as to why authority in Britain is not so much disrespected but rather questioned.

A further example where authority is brought closer to the masses, and not just in name, is Parliament, and to be more precise the House of Commons, the elected legislative body of the British Parliament. Technically the lower House of Commons is predominant over the House of Lords, often the term Parliament is used synonymously with the House of Commons (EB). As the British historian A. F. Pollard states in his book The Evolution of Parliament (1920):

[t]he distinguishing feature of the English parliament is the junction it made between the government and the people. Not that the house of commons was ever intended as a house of the common people, which it is sometimes supposed to have been. For 'commons' means 'communes'. [...]

Common action was, however, commoner among the common people, because they had greater need than individualistic barons of union for self-protection, and it was only under the pressure of exceptional royal tyranny that barons borrowed the methods of association from the humbler townsfolk who first put the fear of communism into the hearts of privileged classes.

Nowadays the House of Commons controls the government's finances, keeps a close eye on government administration and legislates (Parliament UK, Two house system). It is in a position of power and authority, which is not reflected in its name, contrary to the House of Lords, the second half of the same institution. The House of Lords has essential law-making and scrutiny functions, but its powers are limited by a combination of law and convention, for example, bills to authorise expenditure or raise taxes cannot be amended by the Lords (Parliament UK, Role and work). 


\section{PRESENT DAY DIFFERENCES AFFECTING THE PRINCIPLE OF AUTHORITY}

In the following sections of the discussion, attention will focus on presenting differences affecting the Principle of Authority. There are a number of important differences between the Polish and the British ways of recognising and submitting to the Principle of Authority. In the following paragraphs an attempt will be made to analyse the way educational benefits are perceived; the way appearance is considered; the way uniformed services are viewed; the manner in which consumer rights are respected and the impact of the Principle of Authority on the media.

\subsection{The way educational benefits are perceived}

As was mentioned before, the primary attributes of perceiving authority, according to Cialdini (2009), are titles, clothes, and trappings, therefore the Polish and British ways of seeing power should be considered. Academic titles in Poland carry substantial weight. People possessing the title of a doctor or a professor are seen as experts, not only in their chosen field of expertise. In the last few years the number of Ph.D. students has increased dramatically according to Central Statistical Office, but, interestingly, only 20 percent of doctors stated that they intended to stay in academia (European University Institute, 2018). Furthermore, getting a Ph.D. degree nowadays does not guarantee getting a job at university, as it is a somewhat closed system with a limited number of new positions, and very little internal mobility; one usually retires from one's alma mater (European University Institute, 2018). All these facts are known, and yet the need for possessing a title is as great as ever. One of the possible answers is that it provides a feeling of authority and power that people seek so badly. Acquiring a title can take many years and a great deal of hard work, the financial gain is also of little incentive.

\subsection{The way looks are considered}

Clothing is yet another vital factor present when discussing the Rule of Authority. As was stated at the beginning of this paper, people tend to pay more attention to someone wearing a uniform, holding a briefcase or a clipboard. Nonetheless, these garnishes draw attention precisely because they are subconsciously associated with being an expert in a specific field. People possess a considerable need to follow someone, an authoritative figure, while only their authority is judged on the basis of their looks. There is a proverb in English: clothes do not make a man (FD); there is a similar saying in Polish: nie szata zdobi cztowieka. The meaning of both proverbs is the same: people should be judged by their actions, rather than their clothing. Nevertheless, Britain and Poland display a somewhat diverse attitude towards this issue. British people are infamous for their fashion sense partially due to the speed with which fashion retailers introduce style changes (Sorensen 2009: 20), e.g. long fur coats with denim shorts or onesies as favourable ensemble for dropping children off at school in the morning (Groskop and Blanchard, 2016). According to an article in The Guardian, "there is an increasing tendency to escort children to and from school while still wearing pyjamas and, on occasion, even slippers" (Groskop and Blanchard, 2016). Furthermore, the article is summed up in the words: "who are we to judge?" In Poland after a whole day of manual labour one would consider a change of clothes before picking up children from school, even if it meant having to change back again if the work was not finished and the school was just around the corner. This begs the question as to why British people are considered such fashion victims. There is a saying in 
Polish: jak cię widza tak cie pisza meaning that people's opinion of someone is based entirely on their appearance. This may well explain the difference, especially when one considers the dominance of the philosophy of not judging a book by its cover, which is prevalent throughout the UK.

\subsection{The way uniformed services are viewed}

When researching cultural differences between the Polish and the British ways of perceiving authority there is another major reason why a uniform commands more respect in Poland than in the UK. In Poland, police officers carry weapons at all times; however, in Britain, it is not practiced "British police officers are traditionally unarmed, with guns going to those who volunteer and who undergo a high level of training. Only officers in Northern Ireland are routinely armed" (Dodd, 2017). The Police force in Britain was founded in 1829 on the principle of "policing by consent", rather than by force (Smith, 2017). At that time it was believed that "giving everyday police officers guns sends the wrong message to communities, so this thinking goes, and can actually cause more problems than it solves" (Smith, 2017). Nowadays, with terrorist attacks so prominent, opinions are different with more officers showing a desire to carry firearms, according to a new survey conducted by the Police Federation (Dodd, 2017). "Arming all officers would change the power dynamic between the police and the public" (Obordo, 2017). That change may be reflected in the way the police are perceived in Britain. By any means it may be more similar to the way Polish people regard the police, with more respect and a littler fear. It must not be forgotten that capital punishment in the UK was suspended in 1965 and abolished in 1969 (Allen, 2014). That is over thirty years prior to Poland, where until 1997 capital punishment remained a part of Polish law. A life sentence in the UK also does not carry the same weight as it does in Poland. In the UK one is eligible for parole after 15 years in prison (Gov UK n.d.,Types of prison sentences), while in Poland after 25 years (Kancelaria Sejmu, Kodeks karny, art. $78 \mathrm{KK}$ paragraf 3). These facts would imply that, through the power of threat, the justice system - whether it be judicial punishment or the police force - Polish institutions command greater respect and thus wield greater levels of authority.

On the question of authority, there are also differences regarding military service, yet another embodiment of power. Conscription to the army in Britain was introduced in 1945 and abolished in 1957, although it continued till 1960 with the last conscripts demobbed in 1963 (Davenport, 2014). In Poland, national service ended in 2008, that is over fifty years later (Day, 2015). Therefore, for half a century longer Polish people were taught to view military rank as a symbol of authority, and while attitudes may be changing, the hangover from the previous system is still felt in Poland, while in Britain the time gap between compulsory military service and the present has led to a general degradation in how the military is perceived.

\subsection{Media and the principle of authority}

Throughout history Polish people endured extended periods of time while subjected to some kind of control. While the UK exercised freedom of speech, press and religion (Coates, n.d.), in Poland the Soviet-backed communist regime controlled most aspects of life (Clought, 2014). One of the means of control was establishing a Censorship organization. As is stated by John M. Bates in Censorship in Poland, 1976-1989 "[t]he creation of this central body, to which every publication had to be submitted, represented only one dimension of communist control over publishing and in fact, any form of public 
expression" (Bates, 2004). It was only in 1990 that the Central Office for the Control of the Press, Publications, and Spectacles was disbanded by a parliamentary bill (The News, Radio Poland, 2015). In the UK, censorship was abolished much sooner in 1968, by the Theatre Act (Legislation UK, n.d.).It was stated in BBC News that "[c]hanges in society were beginning to grate - and the authorities were forced to revise their attitudes. There was the pressure of a more permissive society in the late 1950s and 1960. [...] Eventually, of course, the idea of censorship was unsustainable, and the Theatre Act was passed. The American hippy musical Hair opened in London just one day later" (BBC Today, 2008).

In October 1977 the premiere of the musical Hair portrayed the hippie culture, the sexual revolution of the 1960s, and anti-Vietnam War peace movement (Billington 2010). Few years later- December 1981 in Poland, behind the iron curtain, Martial Law was introduced to keep citizens under the maximum control of the communist government.

I wonder if the notion of a free press, which has existed in the UK since the $19^{\text {th }}$ century, does not lend itself to the fact that British newspapers are much more respected, and what is written in a paper tends to be treated as gospel fact.

\subsection{The way consumer rights are regarded}

Consumer rights in the UK are protected by the Consumer Act of 2015 (Gov UK, n.d.). Moreover, the UK Ombudsman Association promotes independent complaint resolution and therefore the avoidance of the small claims court (Ombudsman Association, n.d.). There are also 316 Citizen Advice Bureaus which are charitable organisations, offering help in all legal matters to the public since 1939 (Gov UK, n.d.). With so much legal protection it is no wonder that British people feel more confident about their rights, are more knowledgeable in that respect, more prone to question authority, unwilling to obey without asking for the reason first. In contrast, where retail outlets were state-owned until 1989, there was an overriding sense that the shop was infallible. As a consequence, using consumer rights privileges is something that is not a part of the Polish national character, and it is only since Polish accession to the European Union in 2004 that some order has been brought to this area of public life, and Polish people have been directed towards the appropriate legal mechanisms which exist to facilitate the process of pursuing claims against a retailer/service provider.

Cialdini's principles of influence are present in everyday human interactions regardless of the nation, religion, traditions or culture. They can be observed in all aspects of life at all stages of human evolution. Nevertheless, when discussing the Principle of Authority, it may be interesting to look deeper and take into account the cultural elements of a particular country.

\section{CONCLUSIONS}

Beliefs, customs, traditions, values and principles form the foundations of any nation. Because these factors vary between different countries, so do their cultures. Cialdini's theory of influence is universal and can be observed everywhere regardless of the nations' economic or political status. Nevertheless, the economy of a country and politics are integrated into the culture and reflected by it, and therefore human interactions are governed by these elements.

The way we perceive the world around us consists of our combined knowledge of the particular subject and the linguistic skills to express it. Although different nations possess 
different linguistics skills and are capable of expressing their thoughts, the knowledge factor will differ as the combined knowledge of the nation is dictated by that nation's culture.

Cialdini's Principle of Authority stating that people are more likely to obey a person in a position of power is accurate, but the depth of such obedience will depend on the target country's cultural background. That cultural background determines the extent to which people are prepared to follow Cialdini's principle.

\section{REFERENCES}

Allen, K. (2014). Fifty years after the last hanging the UK has fallen out of love with the death penalty. "The Guardian" [Access: 31.03. 2018]. Access on the internet: https://www. theguardian.com/commentisfree/2014/aug/13/fifty-years-hanging-britain-death-penalty.

Amnesty International UK (2018). Northern Ireland abortion: $75 \%$ of UK public want government to change law - new polls [Access: 31.03.2018]. Access on the internet: https://www.amnesty.org.uk/press-releases/northern-ireland-abortion-75-uk-public-wantgovernment-change-law-new-polls.

Arendt, H. (1970). On Violence. London: Allen Lane.

Bates, J.M. (2004) From State Monopoly to a Free Market of Ideas? Censorship in Poland, 1976-1989. Amsterdam-New York: Editions Rodopi B.V.

BBC Today (2008). Censored on stage [Access: 31.03.2018]. Access on the internet: http://news.bbc.co.uk/today/hi/today/newsid_7638000/7638553.stm.

BBC UK The British Museum (n.d.). History of the World, the Magna Carta [Access: 6.02.2018]. Access on the internet: http://www.bbc.co.uk/ahistoryoftheworld/objects/OiBPq_oTBydsT4NnccgSg.

BBC UK. The British Museum (n.d.). History of the World [Access: 6.02.2018]. Access on the internet: http://www.bbc.co.uk/ahistoryoftheworld/objects/OiBPq_-oTBydsT4NnccgSg.

Bierstedt, R. (1960). An Analysis of Social Power. ”American Sociological Review”, Vol. 15. Edited by Scott John, Power, Critical Concept. 2001. London: Routledge.

Billington, M. (2010). Hair. "The Guardian" [Access: 31.03.2018]. Access on the internet: https://www.theguardian.com/stage/2010/apr/14/hair-musical-review.

Breay, C., Harrison J. (2014). Magna Carta: an introduction. "British Library” [Access: 9.03.2019]. Access on the internet: https://www.bl.uk/magna-carta/articles/magna-carta-anintroduction.

Census 2011. Northern Ireland Statistics and Research Agency. Key Statistics for Northern Ireland, Ethnicity, Identity Language and Religion [Access: 30.06.2019]. Access on the internet: https://www.nisra.gov.uk/sites/nisra.gov.uk/files/publications/2011-census-results-keystatistics-northern-ireland-report-11-december-2012.pdf.

Cialdini, R. B. (2009). Influence - the Psychology of Persuasion. New York: Harper Collins e-books.

Clought, P. (2014). Wojciech Jaruzelski Poland's last communist leader. Independent UK [Access: 30.03.2018]. Access on the internet: ttps://www.independent.co.uk/news/obituaries/ wojciech-jaruzelski-polands-last-communist-leader-who-imposed-martial-law-on-the-sovietsatellite-in-9436739.html.

Coates, S. (n.d.). England. The Free Speech and Free Press Around the World [Access: 31.03.2018]. Access on the internet: https://freespeechfreepress.wordpress.com/england.

Cole, G.A. (1998). Organisational Behaviour. London UK: Continuum. 
Dahl, R.A. (1961). Who Governs? Democracy and Power in an American City. New Haven, CT: Yale University Press.

Davenport, R. (2014). National service conscription in Britain 1945-1963. "The Guardian" [Access: 31.03.2018]. Access on the internet: https://www.theguardian.com/books/2014/aug/ 20/national-service-consctiption-britain-richard-vinen-review.

Day, M. (2015). Poland mulls compulsory army training due to Russia fears. "The Telegraph" [Access: 31.03.2018]. Access on the internet: https://www.telegraph.co.uk/news/worldnews/ europe/poland/11464797/Poland-mulls-compulsory-army-training-due-to-Russia-fears.html.

Dodd, V. (2017). Majority of police officers are prepared to carry guns. "The Guardian” UK [Access: 31.03.2018]. Access on the internet: https://www.theguardian.com/uk-news/2017/ sep/22/one-in-three-uk-officers-want-all-police-to-carry-guns-survey-finds.

Dodd, V. (2017). Police in England and Wales to be asked whether they want to carry a gun. “The Guardian" UK [Access: 31.03.2018]. Access on the internet: https://www.theguardian. com/uk-news/2017/jul/27/police-in-england-and-wales-asked-whether-they-want-to-carrya-gun.

Encyclopaedia Britannica (n.d.). House of Commons. British Government [Access: 9.02.2019]. Access on the internet: https://www.britannica.com/topic/House-of-Commons-Britishgovernment\#ref215006.

Encyclopaedia Britannica (n.d.). Parliament [Access:30.03.2018]. Access on the internet: https://www.britannica.com/topic/Parliament.

European University Institute (2018). Poland, Academic Career Structure [Access: 10.02.2018]. Access on the internet: https://www.eui.eu/ProgrammesAndFellowships/AcademicCareers Observatory/AcademicCareersbyCountry/Poland.

Gov. UK (n.d.). Consumer protection rights [Access: 30.03.2018]. Access on the internet: https://www.gov.uk/consumer-protection-rightsdos.

Gov.UK (n.d.). Open Justice [Access: 4.04.2018]. Access on the internet: http://open. justice.gov.uk/courts/civil-cases.

Gov.UK (n.d.). Types of prison sentences [Access: 31.03.2018]. Access on the internet: https://www.gov.uk/types-of-prison-sentence/life-sentences.

Graham-Harrison, E. (2018). Ireland votes to oust 'medieval' blasphemy law. "The Guardian" [Access: 22.11.2018]. Access on the internet: https://www.theguardian.com/world/2018/ oct/27/ireland-votes-to-oust-blasphemy-ban-from-constitution.

Groskop, V., Bkanchard, T. (2016). Is it ok to wear pyjamas in public? "The Guardian” UK [Access: 31.03.2018]. Access on the internet: https://www.theguardian.com/commentisfree/ 2016/jan/30/is-it-ok-to-wear-pyjamas-in-public-darlington-head-teacher-primary-school.

Ibeji, M. (2011). King John and the Magna Carta. BBC History [Access: 6.02.2018]. Access on the internet: http://www.bbc.co.uk/history/british/middle_ages/magna_01.shtml.

Jones, D. (2015). “Magna Carta and kingship.” British Library [Access: 6.02.2018]. Access on the internet: https://www.bl.uk/magna-carta/articles/magna-carta-and-kingship.

Kancelaria Sejmu. n.d. Kodeks Karny [Penal Code] [Access: 9.03.2019]. Access on the internet: http://prawo.sejm.gov.pl/isap.nsf/download.xsp/WDU19970880553/U/D19970553Lj.pdf.

Kelly, B. (2019). Abortion in Northern Ireland: Why terminations are illegal in one part of the UK. Independent [Access: 20.02.2019]. Access on the internet: https://www.independent. co.uk/news/uk/politics/northern-ireland-abortion-illegal-laws-different-uk-pro-life-choicederry-girls-a8797131.html. 
Legislation.gov.UK. n.d. Abolition of censorship of the theatre. [Access: 31.03.2018]. Access on the internet: https://www.legislation.gov.uk/ukpga/1968/54/crossheading/abolition-ofcensorship-of-the-theatre.

Lukes, S. (2005). Power, a Radical View Second Edition. London: Palgrave Macmillan.

McSorley, Ch. (2018). Blasphemy, Stephen Fry and Referendum in Ireland. BBC News [Access: 22.11.2018]. Access on the internet: https://www.bbc.com/news/world-europe-45903094.

Milgram, S. (2017). Obedience to Authority. New York, NY: HarperCollins Publishers.

Morriss, P. (1987). Power - a philosophical analysis. Manchester: Manchester University Press.

Obordo, R. (2017). It would change the power dynamic: police officers on carrying guns. "The Guardian" [Access: 31.03.2018]. Access on the internet: https://www.theguardian.com/uknews/2017/jul/28/it-would-change-the-power-dynamic-police-officers-on-carrying-guns.

Ombudsman Association (n.d.). Promoting independent complaint resolution. [Access: 1.04.2018]. Access on the internet: http://www.ombudsmanassociation.org/find-anombudsman.php.

Parliament UK, House of Lords (n.d.). Role and work [Access:10.02.2018]. Access on the internet: http://www.parliament.uk/documents/lords-information-office/lords-briefingpapers/15595holbriefing-work-role-function.pdf.

Parliament UK. (n.d.), The two house system [Access: 18.03.2019]. Access on the internet: https://www.parliament.uk/about/how/role/system.

Parsons, T. (1963). On the Concept of Political Power. "Proceedings of the American Philosophical Society”. Vol. 107. Edited by Scott John Power, Critical Concept. 2001. London: Routledge.

Paterson, T.T. (1966). Management Theory. London UK: Business Publications Limited.

Pollard, A.F. (1920). The evolution of Parliament. London; New York: Longmans, Green.

Pollard, A.F. (2007). Henry VIII. The Project Gutenberg EBook [Access: 1.03.2019]. Access on the internet: https://www.gutenberg.org/files/20300/20300-h/20300-h.htm\#page001.

Pollard, A.F. (n.d.). The evolution of Parliament. Public Domain Google [Access: 9.02.2018]. Access on the internet: https://babel.hathitrust.org/cgi/pt?id=uc1.\$b22482;view=1up;seq=126.

Roberts, R. (2017). Church of England tells schools to let children explore gender identity. Independent [Access: 6.02.2018]. Access on the internet: http://www.independent.co.uk/ news/uk/home-news/church-of-england-schools-let-children-explore-gender-identitytransgender-gender-fluid-a8051406.html.

Roth, G. "Introduction" to Weber, M. (1968). Economy and Society: An Outline of Interpretive Sociology. Berkeley and Los Angeles: University of California Press.

Russell, B. (1938). Power: A New Social Analysis. London: Allen \& Unwin.

Sentamu, J. (n.d.). Combating racism and celebrating diversity. Archbishop of York [Access: 6.02.2018]. Access on the internet: https://www.archbishopofyork.org/concerns/combatingracism-and-celebrating-diversity.

Sherwood, H. (2016). Faith, hope and secularity: Ireland on brink of change as church powers wanes. "The Guardian" UK [Access: 24.11.2018]. Access on the internet: https://www. theguardian.com/world/2016/feb/17/faith-hope-and-secularity-ireland-on-brink-of-change-aschurch-power-wanes.

Smith, A. (2017). The vast majority of UK police don't carry guns. Here is why. NBC News [Access: 31.03.2018]. Access on the internet: https://www.nbcnews.com/news/world/whylondon-won-t-arm-all-police-despite-severe-terror-n737551. 
Sorensen, C. (2009). Fashion Marketing Third Edition, edited by Mike Easey, United Kingdom: A John Wiley \& Sons, Ltd., Publication.

The Free Dictionary (n.d.). The clothes don't make the man [Access: 31.03.2018]. Access on the internet: https://idioms.thefreedictionary.com/the+clothes+don\%27t+make+the+man.

The News, Radio Poland (2015). Poland marks 25-years since lifting of censorship [Access: 31.03.2018]. Access on the internet: http://www.thenews.pl/1/9/Artykul/203213,Poland-marks25-years-since-lifting-of-censorship.

Weber, M. (1968). Economy and Society: An Outline of Interpretive Sociology. Berkeley and Los Angeles: University of California Press.

Worley, W. (2016). Church of England loses more than 100,000 worshipers in a decade. Independent [Access: 2.02.2018]. Access on the internet: http://www.independent.co.uk/ news/uk/home-news/church-of-england-anglican-statistics-loss-worshipers-decade-sundayattendance-a7384631.html.

DOI: $10.7862 /$ rz.2020.hss.38

The text was submitted to the editorial office: March 2020.

The text was accepted for publication: December 2020. 